\title{
Институт экстрадищии (выдачи): опыт национально-правовой регламентации
}

Сафаров H.A.*

Экстрадиция (выдача) как осуществляемая в отношениях между государствами процедура доставки правонарушителя ${ }^{\mathfrak{1}}$ под компетентную юрисдикцию с целью уголовного преследования либо исполнения назначенного судом наказания ${ }^{2}$, как правило, основывается на положениях международных договоров. Именно нормы договоров позволяют облекать в правовую форму взаимосогласованные обязательства по выдаче лиц, совершивших преступления, добиваться единых подходов к вопросам экстрадиции (правило «двойного вменения», «специализации» и т.д.).

U. Бассиуни, исследуя проблемы выдачи, отмечал, что «государства в целом рассматривают экстрадицию как суверенный акт. Большинство государств исходят из того, что обязательство экстрадиции создается посредством договоров. В отсутствие международных обязательств государства могут взаимодействовать в соответствии с принципом взаимности и вежливости, которые являются частью междуна-

- Сафаров Низами Абдуллаевич - к.ю.н., заведующий отделом Административного и военного законодательства Аппарата Национального Собрания (Парламента) Азербайджанской Республики, эксперт подразделения по борьбе с терроризмом Управления ООН по наркотикам и преступности.

' Термин «правонарушитель» используется для целей данной работы как обозначающий обвиняемых либо осужденных, в отношении которых применяются экстрадиционные процедуры.

${ }^{2}$ См. об этом подробнее: Shearer I. Extradition in International Law. Leiden. 1971; Bassioni C. International Extradition and World Public Order. Leiden, 1974; Chartres B. The Law and Practice of Extradition. F.B. Rothman. 1981; Jones A. Jones on Extradition. London, 1995; Gilbert $G$. Aspects of Extradition Law. Dodrecht, 1991; Ford $M$. The Law of Extradition in UK. London, 1995; Gilbert $G$. Transnational Fugitive Offenders in International Law: Extradition and Other Mechanisms. Dodrecht, 1998; Stanbrook I., Stanbrook C. Extradition Law and Practice. Oxford: Oxford University Press, 2000; Лукаиук Н.И., Наумов $A . B$. Выдача обвиняемых и осужденных в международном уголовном праве. М., 1998; Минкова Ю.В. Принципы института выдачи (экстрадиции) в международном праве. М.: Изд. РУДН, 2002; Волженкина В.М. Выдача в российском уголовном процессе. М.: Юрлитинформ, 2002; Васильев Ю. Институт выдачи преступников (экстрадиции) в современном международном праве. М., 2003; Бойцов А.И. Выдача преступников. СПб.: Изд. «Юрид. центр Пресс», 2004; и др. 
родного принципа взаимного сотрудничества и дружбы между нациями... Государства в отсутствие договорной основы могут удовлетворить либо отклонить экстрадицию в соответствии с национальным законодательством, предусматривающим подобную возможность...» ${ }^{3}$. Таким образом, если государства, вовлеченные в экстрадиционный процесс, не связаны соответствующими обязательствами согласно двусторонним или многосторонним договорам по оказанию правовой помощи либо выдаче правонарушителей, то в этом случае решающая роль будет принадлежать национальному законодательству запрашиваемого государства, дополняющего в качестве важнейшего составного элемента систему правового регулирования экстрадиции.

Экстрадиция представляет собой достаточно сложную юридическую процедуру, которая регулируется различными отраслями национального законодательства, и в частности конституционным, уголовным, утоловно-процессуальным и т.д. Так, к примеру, именно конституционные нормы устанавливают такие фундаментальные принципы (правила) в сфере экстрадиции, как невыдача собственных граждан, отказ от выдачи лица, преследуемого за политические убеждения, исключение отдельных уголовных деяний из категории «защищаемых политических преступлений» ${ }^{4}$ и т.п. Вместе с тем самое непосредственное значение для выдачи имеют консолидированные внутригосударственные правовые акты - национальные законы об экстрадиции.

Практика принятия национальных законов об экстрадиции имеет длительную историю. Достаточно упомянуть, что впервые закон о выдаче был принят в 1833 г. в Бельгии. Затем подобные законы приняли Великобритания (1870 г.), Нидерланды (1875 г.), Швейцария (1892 г.), Франция (1927 г.), Германия (1929 г.) и другие государства ${ }^{5}$. Собственный закон об экстрадиции был принят в 1911 г. и в России. Причем тщательность юридической проработки обеспечила ему полное соответствие европейскому уровню экстрадиционной практики начала XX в. ${ }^{6}$

${ }^{3}$ Bassiouni C. International Extradition: United States Law and Practice. New York: Transnational Publishers, 1996. P. 17. CM. Takee: Botha N. Extradition on the Basis of the Treaty // South African Yearbook of International Law. 2000. Vol. 25. P. 245-255.

${ }^{4}$ Согласно ст. 13 (3) Конституции Испании, не подлежат выдаче лица, совершившие политические преступления, к которым не относятся террористические акты. См. об эrom: Constitutions of Europe. Text Collected by the Council of Europe Venice Commission. Vol. II. Martinus Nifhoff Publishers, 2004.

s Von Moock M. Auslieferungsrechtliche Probleme an der Wende vom. 19 zum 20 Jahrhundert. Nomos, 2001. 
В настоящее же время национальные законы об экстрадиции действуют в Австрии, Бельгии, Германии, Великобритании, Канаде, во Франции, в Израиле, Индии, Испании, Швеции, Исландии, Коста-Рике, Португалии и других странах. Среди государств, ранее входивших в бывший Союз ССР, впервые закон об экстрадиции был принят в 2001 г. Азербайджанской Республикой.

Как показывает сравнительный анализ, национальные законы базируются в основном на одних и тех же исходных, базисных правовых принципах с учетом некоторых особенностей, вытекающих из собственных правовых традиций, специфических черт правовой системы государств и т.д.

Мы уже подчеркивали ведущую роль международного договора (двустороннего либо многостороннего) для регулирования отношений по выдаче. Что же касается национального закона, это незаменимый юридический инструмент в случае отсутствия межгосударственных соглашений. Ссылку на применение национальных законодательных актов в отношении ситуаций, когда между заинтересованными сторонами не сушествует договоров о выдаче, предусматривают законодательство Франции, Азербайджанской Республики и других стран.

Во французском законодательстве, как известно, ранее действовавший Закон об экстрадиции от 10 марта 1927 г. (La loi du 10 mars 1927 relative à l'extradition) в ст. 1 устанавливал, что при отсутствии договора условия, процедуры и последствия экстрадиции определяются положениями данного Закона. Причем он равным образом применяется к пунктам, которые не были регламентированы договорами . И хотя и впоследствии Законом от 9 марта 2004 г. «Об адаптации судопроизводства к эволюции преступности» (Loi portant adaptation de la justice aux évolutions de la criminalité) Закон 1927 г. был отменен, а вопросы экстрадиции были отнесены к сфере регулирования французского уголовно-процессуального кодекса, тем не менее правило, предусмотренное ст. 1 ранее действовавшего Закона об экстрадиции, было включено в ст. 696 УПК $^{8}$.

Закон об экстрадиции Коста-Рики от 16 июля 1971 г. применяется в случае, когда между Коста-Рикой и запрашивающим государством

${ }^{6}$ См. об этом: Родионов К.С. Закон Российской Империи 1911 г. о6 экстрадиции // Государство и право. 2003. № 7. С. 80.

7 J.O.R.F. 11 Mars 1927. P. 2874.

${ }^{8}$ http://www.legifrance.gouv.fr 
отсутствует международный договор. При этом указанный закон был принят во исполнение положений ст. 31 Конституции Коста-Рики, согласно которой экстрадиция регламентируется законом либо международными договорами.

Согласно ст. 1.2 Закона Азербайджанской Республики «О выдаче (экстрадиции) лиц, совершивших преступления» от 15 мая 2001 г. (вступил в силу 19 июня 2001 г.), его положения применяются в случае, когда между Азербайджанской Республикой и запрашивающим иностранным государством не имеетя соответствуюшего договора о выдаче лица, совершившего преступление 9 . Как правило, выдача лиц, совершивших преступления за пределами территории Азербайджанской Республики, осуществляется в соответствии с международными договорами. Закон же применяется в случаях, когда экстрадиция запрашивается иностранным государством, не находящимся с Азербайджанской Республикой в договорных отношениях. Тем самым закон восполняет существенный пробел в правовой системе, поскольку в случаях отсутствия договора не существовало бы правовых механизмов, в рамках которых могла бы быть осуществлена выдача. С другой стороны, принятие закона поставило процесс экстрадиции в четкие правовые рамки, предусмотрев регламентацию всех его стадий: получение запроса, применение принудительных мер к правонарушителю, рассмотрение запроса по сушеству, обжалование принятого решения и т.д. ${ }^{10}$

Надлежит также принимать во внимание, что выдача в отсутствие договора имеет некоторые специфические особенности. В частности, в национальном законодательстве ряда государств действует положение о том, чтобы прежде чем суд приступит к установлению наличия состава преступления, был получен ответ на предварительный вопрос: предусмотрена ли запрашиваюшим государством выдача преступника в аналогичных ситуациях в отношениях государства, к которому предъявлено данное требование, т.е. выдача может быть осуществлена с соблюдением принципа взаимности ${ }^{11}$.

Например, согласно ст. 2 (А) израильского Закона о выдаче 1954 г. (с последующими изменениями), государство Израиль может действовать в экстрадиционных отношениях согласно правилу взаимности.

${ }^{9}$ См. подробнее: Сафаров Н.A. Комментарий к Закону Азербайджанской Республики «О выдаче (экстрадиции) лиц, совершивших преступления». Баку, 2001. С. 9.

${ }^{10}$ Там же. С. 17-18.

"Международное право / Отв. ред. Ю.М. Колосов и Э.С. Кривчикова. М.: Международ. Отношения, 2001. С. 457-458. 
В соответствии со ст. 1.2 Закона Азербайджанской Республики о выдаче его положения применяются с соблюдением принципа взаимности. Причем законодательство не только декларирует взаимность, но и в случае его несоблюдения предусматривает отказ от экстрадиции лица (ст. 3.1.8 Закона о выдаче).

Российская Федерация в вопросах экстрадиции также исходит из принципа взаимности, который предусматривается в уголовнопроцессуальном законодательстве ${ }^{12}$.

Согласно ст. 462 УПК, Российская Федерация на основе принципа взаимности может выдать иностранному государству иностранного гражданина или лицо без гражданства, находящееся на территории Российской Федерации, для уголовного преследования или исполнения приговора за деяния, которые являются уголовно наказуемыми по уголовному закону РФ и законам иностранного государства, направившего запрос о выдаче лица. При этом выдача лица на основе принципа взаимности означает, что в соответствии с заверениями иностранного государства, направившего запрос о выдаче, можно ожидать, что в аналогичной ситуации по запросу Российской Федерации будет произведена выдача. Применение принципа взаимности согласно УПК Российской Федерации распространяется не только на выдачу, осуществляемую из РФ, но и на выдачу, которая запрашивается российской стороной. В соответствии со ст. 460 (1) УПК Российская Федерация может направить иностранному государству запрос о выдаче ей лица для уголовного преследования или для исполнения приговора на основе письменного обязательства Генерального прокурора выдавать. в будущем согласно принципу взаимности этому государству лиц в соответствии с законодательством Российской Федерации ${ }^{13}$.

Федеральный закон Швейцарии «О международной уголовно-правовой взаимопомоши» от 20 марта 1981 г., регулирующий наряду с другими и вопросы экстрадиции, в ст. 8 («взаимность») предусматривает, что запрос удовлетворяется только в случае, если запрашивающее государство обеспечивает взаимность. При этом, если данное требуется конкретной ситуацией, швейцарская сторона может потребовать гарантий взаимности ${ }^{14}$.

\footnotetext{
${ }^{12}$ См. подробнее: Мельникова Э.Б. Международно-правовое сотрудничество в сфере уголовной юстицин. М.: Проспект, 2003.

${ }^{13}$ См.: Уголовно-процессуальный кодекс Российской Федерацин. М., 2002. С. 274-275.

${ }^{14}$ См. об этом: Волеводз А.Г. Международный розыск, арест и конфискация полученных преступным путем денежных средств и имущества (правовые основы и методика). М., 2000. С. 383.
} 
Ссылку на принцип взаимности содержит и уголовное законодательство Республики Беларусь. Согласно ст. 7 (3), при отсутствии международного договора иностранцы или лица без гражданства, совершившие преступление вне пределов территории Республики Беларусь, могут быть выданы иностранному государству на основе принципа взаимности при условии соблюдения требований национального законодательства ${ }^{15}$.

Специфические подходы государств к проблемам экстрадиции проявляются и в вопросах определения сферы выдачи. Если законодательства большинства государств предусматривают в национальных законах выдачу лица из запрашиваемой страны, то в отдельных случаях предусматривается также осуществление выдачи непосредственно в страну. Это, в частности, характерно для канадского закона об экстрадиции 1999 г. До этого, как известно, в Канаде были приняты два закона, регулирующие отношения по выдаче, - Законы «Об экстрадиции» 1877 г. и «О беглых правонарушителях» 1882 г. Новый закон 1999 г., явившийся отражением современных международных стандартов в сфере экстрадиции, регламентирует отношения по выдаче правонарушителей как из Канады (Часть 2), так и в Канаду (Часть 3). Специфические правовые подходы характеризуют и австралийский закон «Об экстрадиции» 1988 г., который регламентирует выдачу: а) из Австралии в запрашивающее государство (часть II); б) из Австралии в Новую Зеландию (часть III); в) в Австралию из третьих стран (часть IV). Напротив, законы Азербайджанской Республики, Исландии, Франции регулируют лишь вопросы выдачи из этих государств.

Как показывает анализ современного национального законодательства об экстрадиции, важнейшая характеристика выдачи, которая привлекла к себе особое внимание, - это ее межтосударственный характер.

Экстрадиция - это процедура, которая применяется только в межгосударственной практике, и этот факт зачастую отражается в конкретных статьях национальных законов (раздел 1 Закона Швеции об экстрадиции за преступления ${ }^{16}$, ст. 1 Закона Азербайджанской Республики о выдаче и т.д.). До недавнего времени межгосударственный характер экстрадиции хотя и упоминался в специальной литературе, но особого акцента на нем не делалось. Однако учреждение международных уголовньг трибуналов ad hoc по бывшей Югославии и Руанде, и в осо-

${ }^{15}$ См.: Уголовный кодекс Республики Беларусь. Санкт-Петербург, 2001. С. 85.

${ }^{16}$ Принят в $1957 \mathrm{r}$. 
бенности Международного уголовного суда (далее МУС либо Суд), осушествление сотрудничества с которыми предполагает перевод или передачу обвиняемых под их юрисдикцию, актуализировало вопрос o разграничении процедур экстрадиции, применяемой в отношениях между государствами, и процедур передачи, применяемой в отношениях государств с международными судебными органами ${ }^{17}$. Хотя международно-правовая практика экстрадиции развивается по пути выработки взаимосогласованных правил, вместе с тем она предусматривает и целый ряд ограничений и запретов на выдачу лиц, предполагающих в каждом конкретном случае применение собственных правовых подходов и оценок государства. Приравнивание запроса о передаче лиц, исходящего от международного трибунала, к запросу об экстрадиции, который исходит от государства, могло бы позволить запрашиваемому государству как исполнить запрос, так и отказать в передаче лица. Между тем Римский статут МУС не позволяет государствам по какимлибо основаниям отказывать в просьбе о передаче лиц ${ }^{18}$. Естественно, что практика экстрадиции, опыт ее правового регулирования активно изучались и использовались в процессе разработки Римского статута, однако модели экстрадиции были модифицированы в той мере, которая была необходима для того, чтобы беспрепятственно осуществлять сотрудничество с МУС в плане передачи лиц под его юрисдикцию ${ }^{19}$.

Учитывая возможность коллизии норм национального права и положений Статута, в ст. 102 проводится дифференциация понятий эк-

${ }^{17} \mathrm{Cм}$. об этом подробнее: Gallant $K$. "Securing the Presence of Defendants Before the International Tribunal for the Former Yugoslavia: Breaking with Extradition", in The Prosecution of International Crimes: A Critical Study of the International Tribunal for the Former Yugoslavia / Ed. by Roger S. Clark and Madeleine Sann. London: Transaction Publishers, 1996. P. 343376; Yong S. Surrendering the Accused to the International Criminal Court // British Yearbook of International Law. 2000. Vol. 71. P. 317-356; Sluiter G. "Co-operation with International Criminal Tribunals for the Former Yugoslavia and Rwanda", in International and National Prosecuton of Crimes Under International Law: Current Developments / Horst Fisher, Claus Kreß, Sascha Rolf Lüder (eds.). Berlin: Verlag Arno Spitz, 2001. P. 681-726; Knoops A. Surrendering to Intemational Criminal Courts: Contemporary Practice and Procedures. New York: Transnational Publishers, 2002. P. 16-42.

${ }^{18}$ См. в частности: Тузмухамедов Б.P. Конституция Российской Федерации и Статут Международного уголовного суда: возможные пути гармонизации // Росснйский ежегодник международного права. 2003. СПб.: Специальный выпуск. С. 124-131.

${ }^{19}$ Cм.: Gupta S. Sanctum War Criminal: Extradition Law and International Criminal Court / / California Criminal Law Review. 2000. Vol. 3; Duffy $H$. National Constitutional Compatibility and International Criminal Court // Duke Journal of Comparative and International Law. 2001. Vol. 11. № 1. 
страдиции (extradition) и передачи (surrender), в соответствии с которыми передача означает доставку лица государством в Суд в соответствии со Статутом, а экстрадиция - доставку лица одним государством в другое государство в соответствии с положениями международного договора, конвенции или национального законодательства ${ }^{20}$. Причем различия, касающиеся содержания указанных понятий, выходят далеко за рамки терминологических характеристик. Речь в данном случае идет о содержательных, фундаментальных различиях двух процедур, разграничение которых было дано в Римском статуте. Кстати, толкование Статута органами конституционной юстиции ряда стран также подтвердило неидентичность правовой природы экстрадиции и передачи лиц.

Конституционный суд Украины в своем заключении по делу о Pимском уставе от 11 июля 2001 г. $^{21}$ указал, что термины «передача» и «выдача» в общеупотребительном понимании часто рассматриваются как синонимы, но в международно-правовых документах и в специальной литературе в них вкладывается различное содержание, что делает их юридическую природу неидентичной... Доставление лица в другое равно суверенное государство принципиально отличается от доставления лица в Суд, созданный согласно международному праву с участием и с согласия заинтересованных сторон... Согласно части второй ст. 25 Конституции Украины, запрешается выдача (экстрадиция) граждан Украины другому государству. То есть запрет касается национальной, а не международной юрисдикции. Он имеет целью га-

${ }^{20}$ Kreß C. "Article 102 - Use of Terms", in Commentary on the Rome Statute of the International Criminal Court: Observer" Notes, Article by Article / Otto Trifferer (ed.). 1 Aufl. Baden-Baden: Nomos Verlag. Ges. 1999. P. 1157-1158 (Рецензию на данное издание см.: Klip A. First In-Depth Study of the International Criminal Court // Criminal Law Forum. 2000. Vol. 11. P. 507-510; Karagiannakis M., Zwanenburg $M$. in Leiden Journal of Intemational Law. 2000. Vol. 13. № 4; Paulus A. Legalist Groundwork for the International Criminal Court: Commentaries on the Statute of the International Criminal Court / European Journal of International Law. 2003. Vol. 14. № 4. P. 843-860); Schabas W. An Introduction to the International Criminal Court. Cambridge: Cambridge University Press, 2001. P. 109113; Swart B. "Arrest and Surrender", in The Rome Statute of the International Criminal Court: A Commentary / Eds. A. Cassese, P. Gaeta, John R.W.D. Jones. Oxford: Oxford University Press. 2002. Vol. II. P. 1639-1704. (Рецензию на данное издание см.: Paulus $A$. Legalist Groundwork for the International Criminal Court: Commentaries on the Statute of the International Criminal Court // European J. Int'l L. 2003. Vol. 14. № 4. P. 843-860; McCormack T., in Melbourn Journal International Law. 2003. Vol. 4. № 1. P. 341-345; Tseng P., in Non-State Actors in International Law. 2004. Vol. 4. № 2. P. 159-165).

${ }_{21}^{21}$ Дело о Риискам Уставе, 11 июля 2001 г., № 3-в. 2001. 
рантировать беспристрастность судебного разбирательства, справедливость и законность наказаний для своих граждан. Международный уголовный суд не может приравниваться к иностранному суду, поскольку создается, как уже отмечалось, с участием и с согласия государствучастников на основе международного, а не национального права. Цель, которой объясняется запрет выдачи граждан одного государства другому, достигается в Международном уголовном суде посредством применения соответствующих положений Устава, разработанных (или одобренных) государствами-участникамн. Эти положения базируются на международных пактах, согласие на обязательность которых для Украины уже дано... Поэтому конституционные положения о запрете выдачи граждан Украины (даже при условии широкого толкования понятия «выдача») нельзя рассматривать отдельно от международноправовых обязательств Украины ${ }^{22}$.

В связи с ратификацией Статута МУС Швейцарией, в частности, необходимо было решить вопрос о том, следует ли вносить изменения в Конституцию (ст. 25 (1)), устанавливающую запрет на высылку граждан и выражение их согласия на экстрадицию иностранному государству, либо участие в деятельности Суда может быть осуществлено и без конституционных реформ. В своем послании от 15 ноября 2000 г. Федеральный совет Швейцарии установил, что ст. 25 (1) Конституции не создает каких-либо препятствий для возможной передачи швейцарского гражданина МУС: «...Сомнительно, что ст. 25 Конституции может быть применена к передаче лица международному трибуналу. Различие между выдачей иностранному государству и передачей лица международному органу - не вопрос формулировки, это различие между двумя понятиями, вытекающее из самого Статута. Статья 102 Статута проводит четкое различие между передачей, которую она определяет как доставку лица государством в Суд, и выдачей, которую она определяет как доставку лица одним государством в другое государство. Следовательно, можно утверждать, что передача Суду не подпадает под действие ст. 25 (1) Конституции, поскольку это положение, по крайней мере на немецком (dürfen ausgeliefert werden) и итальянс-

${ }^{22}$ Сафаров H.A. Передача лиц Международному уголовному суду и институт экстрадиция: трудный компромисс // Московский журнал международного права. 2003. № 2. C. 150-167; Гнатовский Н.Н. Ратификация Римского статута Международного утоловного суда: позиция Украины // Российский ежегодник международного права. Специальный выпуск. СПб., 2003. С. 179-187. 
ком (possono essere eastradate) языках, относится только к выдаче (экстрадиции)...» ${ }^{23}$.

Новейшее развитие института экстрадиции не может не учитывать современных тенденций международного уголовного права, связанных, в частности, с разграничением процедур экстрадиции и передачи лиц, которое в ряде случаев адекватно отражается в национальных законах. В этом плане может быть упомянут Закон Азербайджанской Республики о выдаче, ст. 1.3 которого предусмотрела, что его положения не распространяются на передачу лица международным судебным органам. По смыслу данной статьи Закон регламентирует исключительно вопросы экстрадиции, осушествляемой в межгосударственной практике, не затрагивая передачи лиц под юрисдикцию международных судебных органов ${ }^{24}$. Последняя регулируется Уставами Международных уголовных трибуналов и национальными законами о сотрудничестве с ними ${ }^{25}$.

Грузия в порядке имплементации Римского статута $\mathrm{MУC}^{26}$ в августе 2003 г. внесла изменения в национальное законодательство, согласно которым было произведено разграничение «экстрадиции» и «передачи лиц». В частности, согпасно параграфу 46 ст. 44 УПК Грузии, для цели международного сотрудничества по правовым вопросам передача означает доставку лица государством в Международный уголовный суд согласно его Статуту, а экстрадиция означает доставку лица одним государством другому в соответствии с международным соглашением либо национальным законодательством ${ }^{27}$.

${ }^{23} \mathrm{Cм}$. подробнее: Торманн $O$. Вопросы, поднимавшиеся в связи с ратификацией Статута МУС в Швейцарии // Российский ежегодник международного права. Специальный выпуск. СПб., 2003. С. 104-107.

${ }^{24} \mathrm{CM}$. об этом подробнее: Сафаров $H$. Комментарий к Закону Азербайджанской Республики «О выдаче (экстрадиции)». С. 18-27.

${ }^{25}$ Например, подобные законы были приняты в связи имплементацией Римского статута МУС. В этом плане можно сослаться на германский Закон о сотрудничестве $c$ Международным уголовным судом от 21 июня 2002 г. (Gesetz zur Ausführung des Römishen Statuts des Internationalen Strafgerichtshofes vom. 17 Juli 1998). Подробнее об этом акте см.: Wilkitzki P. The German Law on Cooperation with the ICC // International Criminal Law Review. 2002. Vol. 2. № 2. P. 195-212. Другим примером подобного рода является Закон о Международном уголовном суде 2001 г., принятый в Великобритании (International Criminal Court Act 2001). См. об этом: Turns D. “Aspects of National Implementation of the Rome Statute: The United Kingdom and Selected Other States", in The Permanent International Criminal Court / McGoldrick D., Rowe P., Donelly E. (eds). Oxford: Hart Publishing, 2004. P. 337-388.

${ }^{26}$ Грузия явилась вторым государством - участником СНГ (после Таджикистана), paтифицировавшим Статут МУС 5 сентября 2003 r.

${ }^{27} \mathrm{http}: / / \mathrm{www}$.parliament.ge/LEGAL_ACTS/kanon_en.html 
Существенным моментом в плане обеспечения выдачи правонарушителей является определение круга экстрадиционных преступлений, составляющих, вне всякого сомнения, основу национального закона в целом. Прежде всего отметим, что указанные деяния должны соответствовать правилу (принципу) «двойного вменения», согласно которому лицо выдается в тех случаях, когда совершенное им деяние признается преступным по законодательству как запрашивающего, так и запрашиваемого государства ${ }^{28}$.

Институт международного права в известной Оксфордской резолюции, принятой на конференции института международного права в 1880 году и сформулировавшей основные принципы экстрадиции, указывал на необходимость того, чтобы деяния, к которым применяется выдача, были наказуемы по законодательству обоих государств как запрашивающего, так и запрашиваемого ${ }^{29}$.

При этом не требуется совпадения правового наименования деяния, достаточно, если действия, признаваемые преступлением в запрашивающем государстве, составляют преступление и в стране, в которой беглец разыскивается для выдачи ${ }^{30}$.

. Принцип «двойного вменения» с учетом его значения для экстрадиции лица закреплен в национальных законах о выдаче. В качестве иллюстрации можно сослаться на законы Канады (ст. 3), Швеции (раздел 4).

Азербайджанское законодательство предусматривает, что лицо, экстрадиция которого запрашивается иностранным государством, может быть выдано лишь в том случае, если совершенное им деяние признается преступлением по законодательству Азербайджанской Республики и запрашивающего государства (ст. 2 Закона о выдаче). Осуществление экстрадиции предполагает одинаковый подход к совершенному деянию, которое должно квалифицироваться в качестве преступления по уголовному законодательству Азербайджанской Республики и запрашивающего государства. Экстрадиция была бы невозможна, если подавался запрос о выдаче за деяние, которое расценивалось бы иностранным государством как преступление, а Азербайджанской Республикой рассматривалось в качестве административно-

${ }^{28}$ Plachta $M$. "The Role of Double Criminality in International Cooperation in Penal Matters", in Double Criminality: Studies in International Criminal Law/ Jareborg N. (ed.). Iustus Förlag: Uppsala. 1989. P. 84-134.

29 American Journal of International Law. 1935. № 1-2. P. 300-301.

${ }^{30}$ Bedi S. Op. cit. P. 76. См. подробнее: Bledsoe R., Boczek B. International Law Dictionary. Santa Barbara, 1987. P. 100. 
го проступка либо не квалифицировалось бы в качестве преступления вообще. Выдача как межгосударственный акт правовой помощи по уголовным делам требует наличия взаимосогласованных подходов.

Однако принцип «двойного вменения» сам по себе еще не гарантирует того, что экстрадиция будет осуществлена. Для этого необходимо, чтобы соответствующее преступление отвечало установленному в национальных законах требованию о минимальном пределе лишения свободы. Именно критерий тяжести уголовного наказания берет за основу внутригосударственное законодательство в вопросах установления круга экстрадиционных преступлений. При этом длительность срока наказания различается в зависимости от того, запрашивается ли выдача для уголовного преследования либо для отбытия назначенного наказания. Согласно ст. 3 исландского закона об экстрадиции для привлечения к уголовной ответственности лицо может быть выдано иностранному государству в тех случаях, когда за совершение соответствующего деяния срок предусмотренного наказания в виде лишения свободы составляет не менее одного года. Если же речь идет о выдаче осужденного, то срок лишения свободы не должен быть менее 4 месяцев.

В соответствии со ст. 2.1 Закона Азербайджанской Республики о выдаче лицо, выдача которого запрашивается иностранным государством, может быть выдано лишь в том случае, если за совершенное им деяние предусматривается наказание в виде лишения свободы на срок не менее одного года или более суровое наказание. Что же касается осужденного, то разрешение на его экстрадицию дается лишь в том случае, если неотбытый срок лишения свободы составляет не менее шести месяцев.

Согласно ст. 2 израильского Закона о выдаче, экстрадиционным является преступление, наказуемое лишением свободы на срок не менее одного года либо другим более тяжким наказанием.

Общее признание в экстрадиционном законодательстве получило также правило о том, что лицо может привлекаться к уголовной ответственности только за то деяние, которое явилось основой для экстрадиции.

Выдавая лицо, совершившее преступление, государство, на территории которого оно находилось, исходит из того, что пределы его преследования будут ограничены лишь деянием, указанным в запросе о выдаче. Выход за его рамки означал бы нарушение согласованных 
правил, регламентирующих выдачу преступников, и мог бы привести к неправомерному увеличению объема уголовного преследования. Осуществление выдачи затрагивает сферу межгосударственных отношений, и выход за пределы требования о выдаче возможен лишь при согласии выдавшей преступника стороны. Поэтому экстрадиционные законы прямо предусматривают ссылку на правило (принцип) «специализации»" . В частности, согласно $\$ 11$ ("Speziälitat") германского Закона о международной помощи по уголовным делам от 23 декабря $1982 \Gamma_{.}^{32}$, экстрадиция может быть осуществлена в том случае, если обвиняемый не будет подвергнут наказанию в запрашивающем государстве за преступление иное, нежели деяние, которым была обоснована экстрадиция.

Принципа специализации придерживается и азербайджанское законодательство. Статья 4.1 Закона о выдаче предусматривает, что лицо, выданное по запросу иностранного государства, может преследоваться в порядке, предусмотренном законодательством данного государства, только за преступление, являющееся основанием для его выдачи. Согласно данной норме, осуществление уголовного преследования за преступление, не явившееся основанием для экстрадиции, не допускается. Выданное лицо может быть осуждено лишь за деяние, подпадающее под категорию экстрадиционного по смыслу данного Закона, которое предусматривалось в запросе о выдаче. Хотя ст. 4.1 предусматривает защиту только от осуждения за иное преступление, в совокупности со ст. 4.2 индивиду обеспечиваются гарантии от привлечения к уголовной ответственности либо выдачи третьему государству, что существенно расширяет рамки правовой защиты.

Закон об экстрадиции Великобритании 2003 г. даже рассматривает несоблюдение специализации в качестве основания для отказа от выдачи. Согласно ст. 11 («Запреты на экстрадицию») Закона об экстради-

${ }^{31}$ Указанное правило (принцип) именуют также правилом «конкретности», нормой «о неизменности условий». См. о «специализации»: Ching Hsu. Du principe de la specialite en materiere d'eztradition (etudes de droit compare). Lausanne: Machtzum. 1950. P. 115; Zairi A. Le principe de la specialite de l' extradition au regard des droits de l'homme // Libr. Generale de Droit et de Jurisprudence, 1992. Paris. P. 181; Barett J. The Doctrine of Speciality; À Traditional Approach to the Issue Standing // Case Western Reserve Joumal of International Law. 1997. Vol. 29. № 2. P. 299-320.

${ }^{32}$ Gesetz über die Internationale Rechtshilfe in Strafsachen (BGBI I 1982. S. 2071) // http:/ /www.bundesrecht.juris.de Английскую версию Закона см.: International Legal Materials. 1985. Vol. XXIV. № 1. P. 945-982. 
ции судья, рассматривающий вопрос о выдаче лица, может отказать в экстрадиции в силу несоблюдения правила специализации. Интерпретация же правила специализации содержится в ст. $17^{33}$. Аналогичная позиция характерна и для мальтийского Закона об экстрадиции 2004 г., устанавливающего запрет на выдачу в страны, не соблюдаюшие правило «специализации» (ст. 13 (1, “e”)).

В то же время надлежит учитывать, что правовая защита выданного лица, гарантирующая уголовное преследование в пределах преступления либо преступлений, послуживших основанием для экстрадиции, и невозімжность выхода за пределы запроса без согласия выдавшей стороны имеет определенные временные ограничения. Условие о необходимости получения согласия на привлечение к ответственности за иное преступление либо реэкстрадицию лица третьему государству теряет силу в случаях если:

a) выданное лицо по истечении определенного срока не покидает территорию государства после отбытия наказания или в случае освобождения по любому законному основанию;

б) лицо добровольно возвращается на территорию государства, которому было выдано, после того, как уже покинуло его.

Анализ экстрадиционного законодательства не может абстрагироваться от того факта, что, даже несмотря на значительную правовую урегулированность сферы выдачи, государства при решении конкретных вопросов экстрадиции обладают определенной свободой усмотрения, которая позволяет достаточно либерально толковать нормы национального законодательства. Подобное толкование позволяет в каждом конкретном случае в максимальной степени обеспечивать учет самых различных факторов, влияющих на принятие решения об экстрадиции. Это относится главным образом к необходимости обеспечения правозащитного фактора в процессе экстрадиции. Процесс интернационализации прав человека не мог не затронуть такой сферы международного сотрудничества в борьбе с преступностью, как экстрадиции ${ }^{34}$. Хотя историческое развитие экстрадиции свидетельствует ${ }^{33}$ См. подробнее о Законе 2003 г.: Knowles $J$. Blackstone's guide to the Extradition Act 2003. Oxford: Oxford University Press, 2004; Hardy J. The Law and Practice of Extradition. London: Butterworths, 2004; Sambei A., Jones J. Extradition Law Handbook. Oxford: Oxford University Press, 2005.

${ }^{34}$ Currie R. Human Rights and International Mutual Legal Assistance: Resolving the Tension // Criminal Law Forum. 2000. Vol. 11. № 2. P. 143-181; Harrington J. "Human Rights Exceptions to Extradition: Moving Beyond Risks of Torture and Ill-Treatment"// http:// www.isrcl.org/Papers/Harrington.pdf 
о постепенном утверждении в экстрадиционном процессе позитивного отношения к обеспечению прав личности, принятие основополагающих документов, определивших международные стандарты прав человека и предусмотревших институциональные механизмы их защиты, вне всякого сомнения, оказало существенное влияние на содержание рассматриваемого правового института. Такие международноправовые акты, как Всеобщая декларация прав человека 1948 г., Европейская конвенция о защите прав человека и основных свобод 1950 г., Международный пакт о гражданских и политических правах 1966 г. и другие, обусловили в целом определенное переосмысление экстрадиции, связанное с необходимостью обеспечения международных стандартов прав человека в связи с выдачей. Обязательства государств в области защиты прав человека требуют тщательно рассматривать вопрос о возможном нарушении прав экстрадируемого, связанном с возможным преследованием по мотивам вероисповедания, политических убеждений, расовой принадлежности, с отсутствием минимальных гарантий в процессе судебного разбирательства и т.д. ${ }^{35}$. Несмотря на то, что подобные проблемы существенным образом усложняют экстрадицию лица, в целом использование различных правовых институтов в борьбе с преступностью не может игнорировать международнопризнанные права человека и должно опираться на безусловное предоставление правовых гарантий лицу, в отношении которого применяются соответствующие принудительные меры ${ }^{36}$. И хотя международные договоры по экстрадиции нацелены на поиск соответствующего равновесия между обеспечением защиты фундаментальных прав индивида и необходимостью эффективного функционирования системы экстрадиции, вне всякого сомнения, международное право

${ }^{35}$ См. в частности: Wilson $R$. Toward the Enforcement of Universal Human Rights through Abrogation of the Rule Non-Inquiry in Extradition // ILSA Joumal of International and Comparative Law. 1997. Vol. 3. № 2. P. 751-765; Zuelke S., Pastille J-C. Extradition and European Convention - Soering Revisited // Zeitschrift für ausländisches öffentliches Recht und Völkerrecht. 1999. № 3. S. 749-784; Pyle C. Extradition, Politics and Human Rights. Phikadelphia: Temple University Press. 2001; Blakesley C. Ruminations on Extradition and Human Rights // Strafrecht, Srafprozessrecht und Menschenrechte. 2002. S.191-217; The Individual as Subject of International Cooperation in Criminal Matters: A Comparative Study I Albin Eser, Otto Lagodny, Christofer Blakesley (eds). Berlin: Nomos. 2002; Borelli S. Terrorism and Human Rights: Treatment of Terrorist Suspect and Limits on International Cooperation // Leiden Journal of International Law. 2003. Vol. 16. № 4. P. 803-820.

${ }^{36}$ Сафаров $H$. Обеспечение прав человека и экстрадиционный процесс // Вестник Межпарламентской Ассамблеи. Санкт-Петербург. № 3. 2000. С. 229-230. 
требует, чтобы экстрадиционные процедуры принимали во внимание общие принципы прав человека ${ }^{37}$.

Юридическая защита экстрадируемого приобрела в настоящее время характер устойчивой правовой тенденции, характеризующей не только международно-правовую практнку, но и практику принятия национальных законов об экстрадиции. Даже несмотря на то, что экстрадиция запрашивается в отношении лица, обвиняемого в совершении преступления либо осужденного, данное обстоятельство не только не исключает, а наоборот, актуализирует необходимость обеспечения зашиты его прав. Запрашиваемое государство не может не принимать во внимание того, что его действия по экстрадиции могут иметь в качестве последствия нарушение фундаментальных прав человека, а ведь данное обстоятельство, в свою очередь, может обусловить международно-правовую ответственность государства ${ }^{38}$. Это однозначно подтверждает практика международных судебных (квазисудебных) органов (и в частности Европейского суда по правам человека, Комитета по правам человека) ${ }^{39}$. Нельзя не принимать во внимание, что проблемы, связанные с обеспечением правозащитного фактора, находятся под пристальным вниманием национальных судебных органов, включая органы конституционной юстиции ${ }^{40}$.

Что же касается международных институций, то наиболее известным судебным прецедентом, оказавшим значительное влияние на формирование международной договорно-правовой и национальной юридической практики, явилось дело Soering vs. United Kingdom ${ }^{41}$. В том деле, связанном с выдачей немецкого гражданина по обвинению в убийстве, совершенном в США, где ему грозила смертная казнь, Великоб-

${ }^{37}$ Bantekas I., Nash S. International Criminal Law. Sec. ed. London: Cavendish Publishing Limited. 2003. P. 205-206.

${ }^{38}$ Merrills $J$. The Development of International Law by the European Court of Human Rights. Second ed. Manchester University Press, 1995. P. 109-113. См. подробнее: Гусейнов $J$. Международно-правовая ответственность государств за нарушения прав человека. Киев, 2000.

${ }^{39}$ См. подробнее: De Merieux M. Extradition as the Violation of Human Rights: the Jurisprudence of the International Covenant on Civil and Political Rights // Netherlands Quarterly of Human Rights. 1996. Vol. 14. № 1. P. 23-33.

${ }^{40} \mathrm{CM}$., в частности: Nickel R. Extradition, Human Rights and Public Order - The Extradition to India - Decision of the FCC // German Law Journal. 2003. Vol. 4. № 12. P. 1241-1254. 2003 Hartwig M. The German Federal Constitutional Court and the Extradition of Alleged Terrorists to the United States // German Law Journal. 2004. Vol. 5. № 3. P. 185-195. ${ }^{41}$ Case of Soering vs. United Kingdom (1989). Series A. № 161. 
ритания утверждала, что Конвенция устанавливает обязательства только для Договаривающихся Сторон, которые, в свою очередь, не могут нести ответственность за действия, которые происходят за пределами его юрисдикции. В частности, указывалось, что экстрадиция не влечет за собой ответственности выдающего государства за бесчеловечное или унижающее достоинство обращение или наказание, которым выданное лицо может подвергнуться за пределами этой юрисдикции. Согласно утверждениям Великобритании, это вытекает из основополагающих принципов экстрадиции в государства, не являющиеся участниками Европейской конвенции о правах человека.

Европейский суд по правам человека не согласился с подобной постановкой вопроса, отметив, что вряд ли было бы совместимым с конвенционными ценностями (имеется в виду Европейская конвенция о защите прав человека), если бы Договаривающееся государство заведомо выдало бы беглого правонарушителя государству, в котором имеются все основания полагать, что он оказался бы перед угрозой применения пыток, бесчеловечного или унижающего достоинство обрашения или наказания. Экстрадиция при подобных обстоятельствах, хотя об этом нет прямого упоминания в ст. 3, находилась бы в явном противоречии с духом и целью указанной статьи, невзирая на то, какое гнусное преступление совершило лицо. Суд, таким образом, пришел к заключению, что решение Договаривающегося государства о выдаче может обусловить нарушение статьи 3 Конвенции и тем самым обусловить ответственность государства при наличии оснований полагать, что данное лицо в случае его выдачи ожидает реальный риск подвергнуться пыткам либо бесчеловечному или унижающему достоинство обращению или наказанию ${ }^{42}$.

Необходимость согласования экстрадиции и защиты прав человека - одно из основных требований, пронизывающих весь процесс выда-

${ }^{42} \mathrm{CM}$. о6 этом: Lillich $R$. Soering Case // American Journal of International Law. Vol. 85. 1990. P. 128; Gomien D, Harris D., Zwaak L. Law and Practice of the European Convention on Human Rights. Strasbourg, 1996. P. 116; Bailey S., Harris D., Jones B. Civil liberties. Cases and Materials. Fourth edition. London: Butterworths. 1995. P. 759-763; Shea M. Expanding Judicial Scrutiny of Human Rights in Extradition cases after Soering // Yale Journal of International Law. 1992. Vol. 17. P. 85; Van den Wyngaert C. Applying the European Convention on Human Rights to Extradition: Opening Pandora's Box? // International and Comparative Law Quarterly. 1990. Vol. 37. P. 757, 759; Гусейнов Л. Международные обязательства государств в области прав человека. Баку. 1998. С. 125-127; Европейский суд по правам человека. Избранные решения: В 2 т. Т. 1 / Под ред. В. Туманова. М., 2000. C. 637-659. 
чи, учитывая, что данная процедура существенным образом ограничивает целый комплекс различных прав и свобод индивида ${ }^{43}$.

В литературе отмечается, что новые экстрадиционные договоры и дополнительные протоколы к существующим договорам принимают во внимание фактор прав человека и регулируют это [экстрадицию] таким образом, чтобы суды и исполнительные власти, осуществляя свои полномочия... обеспечивали баланс интересов прав беглых правонарушителей и правопринуждения ${ }^{44}$. Соглашаясь с данным утверждением, в то же время важно подчеркнуть, что не только договоры, но и национальные законы должны исходить из безусловного признания и защиты прав личности в экстрадиционном процессе. Практика принятия таких законов - наглядное тому подтверждение. Причем в отдельных случаях потенциальная несовместимость правозащитных обязательств с экстрадицией может обусловить отказ от выдачи. Например, согласно ст. 6 (1) португальского Закона «О международном правовом сотрудничестве по уголовным делам» ${ }^{45}$, который регулирует вопросы экстрадиции, в сотрудничестве отказывается в случае, если процесс по делу лица не соответствует требованиям Европейской конвенции о защите прав человека и основных свобод от 4 ноября 1950 г. либо другого соответствующего международного договора, ратифицированного Португалией ${ }^{46}$. Как указывается в Инструкции федерального ведомства юстиции Швейцарии, серьезные ошибки зарубежного судопроизводства, а именно нарушение принципов Европейской конвенции о защите прав человека 1950 г. либо Международного пакта о гражданских и политических правах 1966 г, могут привести к отказу от сотрудничества. В качестве подобных ошибок расцениваются

${ }^{43}$ Gross E. Legal Aspects of Tackling Terrorism: The Balance Between the Right of A Democracy to Defend Itself and the Protection of Human Rights // UCLA Journal of International Law and Foreign Affairs. 2001. Vol. 6. № 1; Fenwick $H$. Civil Liberties and Human Rights. Third ed. London: Cavendish Publishing. 2002. P. 959; Thomas R. A Delicate Balance: Extradition, Sovereignty and Individual Rights in the United States and Canada // The Yale Joumal of International Law. 2002. Vol. 27. № 1. P. 193-215; De Than C., Shorts E. International Criminal Law and Human Rights. London: Sweet\&Maxwell. 2003. P. 46-47. ${ }^{4}$ Dugard J., Van den Wyngaert C. Reconciling Extradition With Human Rights / American Journal of International Law. 1998. Vol. 92. P. 212.

${ }^{45}$ Принят 31 августа $1999 \mathrm{r}$.

46 Термин «международное правовое сотрудничество» для целей настонщего Закона согласно ст. 1 (1) предусматривает экстрадицию, передачу производства по уголовным делам, исполнение приговоров, взаимную правовую помощь по уголовным делам и т.д. 
прежде всего серьезные нарушения ст. 5 (правомерность ареста, предъявление обвинений, судебная проверка обоснованности содержания под стражей) и ст. 6 (право на защиту, право на компетентную и справедливую судейскую оценку, презумпцию невиновности и т.д.) ${ }^{47}$.

Кроме того, в основаниях отказа от выдачи находит свое подтверждение тот факт, что экстрадиция не может абстрагироваться от таких обстоятельств, как возможность вынесения смертньх приговоров, опасность подвергнуться пыткам либо бесчеловечному, унижающему достоинство обращению или наказанию, быть судимым без предоставления соответствующих процессуальных гарантий и т.д. ${ }^{48}$, предусматриваемых национальным законодательством. В этом отношении можно сослаться на Закон Великобритании об экстрадиции 2003 г. (ст. 11), который включил возможность нарушения права на равенство в перечень оснований, препятствующих выдаче лица. При этом ст. 13 предусмотрела, что выдача лица не допускается, если соответствующий ордер (warrant) хотя и издан в отношении экстрадиционного преступления, однако фактически предъявлен в целях преследования или наказания лица на основании его расы, религии, национальной принадлежности, пола, половой ориентации либо политических взглядов, или в случае его выдачи суд над этим лицом мог бы носить предвзятый характер, или он мог быть наказан, заключен под стражу или какимлибо иным образом ограничен в своей свободе на основании его расы, религии или национальной принадлежности, пола, половой ориентации или политических взглядов.

Закон Азербайджанской Республики о выдаче (ст. 3) предусматривает развернутый перечень оснований для отказа от выдачи, связанных с необходимостью зашиты фундаментальных прав лица. В их числе предоставление убежища запрашиваемому лицу на территории Азербайджана, возможность вынесения смертного приговора, нарушение права на равенство, возможность подвергнуться пыткам, жестокому, бесчеловечному либо унижающему достоинство обращению или наказанию.

Серьезным фактором, ограничивающим выдачу, является возможность применения отдельных видов наказания за экстрадиционное

${ }^{47}$ Международная правовая помощь по уголовным делам. Инструкщия. Издание № 8 за 1998 г. Цюрих. С. 7.

${ }^{48}$ Nanda $V$. Bases for Refusing International Extradition Requests - Capital Punishment and Torture // Fordham International Law Journal. Vol. 23. 2000. P. 1369-1396. 
преступление. В их числе смертная казнь, а в отдельных случаях и пожизненное заключение ${ }^{49}$. В этом отношении национальное законодательство о выдаче, предусматривая возможность отказа от экстрадиции за преступления, наказуемые смертной казнью, отражает тенденцию ограничения применения указанного уголовного наказания, которое предусматривают как международные юридические инструменты по правам человека ${ }^{50}$, так и экстрадиционные договоры ${ }^{5 !}$.

В качестве примера можно сослаться на ст. 44 (2) канадского Закона об экстрадиции, согласно которой в выдаче может быть отказано в случае, есл́и по законодательству запрашивающего государства предусмотрена смертная казнь за экстрадиционное преступление.

${ }^{49}$ Gregg $R$. The European Tendency Toward Non-Extradition to the United States in Capital Cases: Trends, Assurances and Breaches of Duty // International and Comparative Law Quarterly. 2002. Vol. 10. P. 113-128; King K. The Death Penalty, Extradition and the War Against Terrorism: U.S. Responses to European Opinion about Capital Punishment // Buffalo Human Rights Law Review. 2003. Vol. 9. P. 161-199; Clarke A. Terrorism, Extradition and Death Penalty // William Mitchell Law Review. 2003. Vol. 29. № 3. P. 783-808; Kelly M. Cheating Justice by Cheating Death: The Doctrinal Collusion for Prosecuting Foreign Terrorists - Passage of Aut Dedere Aut Judicare into Customary Law and Refusal to Extradite Based on the Death Penalty // Arizona Joumal of International and Comparative Law. 2003. Vol. 20. № 3. P. 491-532; Labuschange J.M.T., Michele O. Extradition, Human Rights and the Death Penalty: Observations on the Process of the Internationalisation of Criminal Justice // South African Yearbook of International Law. 2003. Vol. 28. P. 131-156; Mc Donnell T.M. The Death Penalty - An Obstacle to the "War against Terrorism" // Vanderbilt Joumal of Transnational Law. 2004. Vol. 37. № 2. P. 353-429; Yorke J. Europe's Judicial Inquiry in Extradition Cases: Closing the Door on the Death Penalty // European Law Review. 2004. Vol. 29. № 4. P. 546-556.

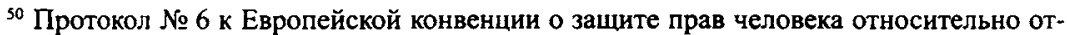
мены смертной казни от 28 апреля 1983 г., исходя из того, что развитие, имевшее место в государствах - членах Совета Европы, отражает общую тенденцию в пользу отмены смертной казни, в ст. I предусмотрел, что смертная казнь отменяется и никто не может быть приговорен к смертной казни или казнен. В соответствии со ст. 2 Протокола государство может предусмотреть в своем законодательстве смертную казнь лишь за действия, совершенные во время войны или при неизбежной угрозе войны. Качественно иной, по сравнению с ранее принятым, подход к смертной казни в рамках Совета Европы был связан с принятием Протокола № 13 от 5 мая 2002 г. к Конвенции о защите прав человека, относительно отмены смертной казни во всех случаях. Согласно ст. 1 Протокола смертная казнь отменяется. Никто не может быть осужден к такому наказанию и казнен. Как указывается в пояснительном докладе к положениям протокола, отмена смертной казни подтверждена в Протоколе как принцип, что влечет за собой отказ от смертной казни во всех случаях за любые деяния, включая действия, совершенные во время войны либо при неизбежной угрозе войны. См.: http:// conventions.coe.int/Treaty/en/Treaties/Htm/187.htm. См. об этом также: Tyзмухамедов Б.P. Протокол об отмене смертной казни // Московский журнал международного права. 2004. № 2. С. 266-271. 
В соответствии со ст. 3.2.1 Закона Азербайджанской Республики о выдаче предусматривается, что в экстрадиции лица может быть отказано в случае, если за преступление, являющееся основанием для экстрадиций по законодательству запрашиваюшего иностранного государства, предусмотрена смертная казнь. Для применения данной статьи достаточно установить, что действующее законодательство запрашивающего государства в санкции статьи, устанавливающей ответственность за преступление, являющееся основанием для выдачи лица, предусматривает смертную казнь. При этом во внимание не принимается наличие других видов уголовного наказания, которые могут быть назначены лицу. Определяющим в этом вопросе является сама возможность вынесения смертного приговора ${ }^{52}$. Вместе с тем указанную норму необходимо рассматривать во взаимосвязи с примечанием к ст. 3 , которая в пункте 2 в качестве изъятия из общего правила о невыдаче лица, совершившего преступление, караемое смертной казнью, допускает экстрадицию лишь в том случае, когда запрашивающее государство предоставляет гарантии неприменения данного наказания.

В соответствии со ст. 37 Федерального закона Швейцарии о международной уголовно-правовой взаимопомощи в выдаче отказывается, если запрашивающее государство не дает гарантии того, что преследуемое лицо не будет осуждено к смертной казни, либо если подобный приговор был вынесен, то он не будет приводиться в исполнение.

Португальский закон «О международном правовом сотрудничестве по уголовным делам» согласно ст. 6 (1, “f') запрещает экстрадицию в случае возможного назначения не только смертной казни, но и пожизненного заключения ${ }^{53}$.

${ }^{51}$ В соответствии со ст. 11 Европейской конвенции об экстрадиции, если преступление, за которое запрашивается экстрадиция, наказуемо смертной казнью по законам запрашивающей Стороны и если за то же преступление по закону запрашиваемой Стороны смертная казнь не предусматривается или смертная казнь не исполняется, в экстрадиции может быть отказано, если запрашивающая Сторона не дает уверения о неприведении смертного приговора в исполнение. См. подробнее: Сафаров Н.A. Европейская конвенция об экстрадиции: комментарий к статъе 11 - «смертная казнь» // Уголовное право. 2003. № 3. С. 120-122.

52 Сафаров $H$. Комментарий к Закону Азербайджанской Республики «О выдаче (экстрадиции) лиц, совершивших преступления». С. 77.

53 Указанная норма отвечает конституционным подходам Португалии. Согласно ст. 30 (1) Конституции страны, запрещены наказания и меры пресечения, лишающие свободы или ограничивающие ее, если они носят постоянный характер либо установлены на неограниченный или неопределенный срок. Необходимо таюже учесть, что в соответствии с конституционной нормой при ратификации Европейской конвенции 
Законы об экстрадиции Швеции (ст. 8) и Исландии (ст. 7) помимо вышеуказанных предусматривают также возможность отказа от выдачи по гуманитарным соображениям, таким как возраст либо состояние здоровья лица.

Широко распространенным основанием для отказа от выдачи является принадлежность к гражданству запрашиваемого государства. Как правило, собственные граждане экстрадиции не подлежат ${ }^{54}$. Национальные законодательства об экстрадиции (законы об экстрадиции, уголовные и уголовно-процессуальные кодексы) подавляюшего большинства́ стран воспроизводят указанное правило.

В частности, французский УПК согласно ст. 696-4 (1) не допускает выдачу иностранному государству лица, являющегося французским гражданином. Аналогичное правило предусматривает и ст. 464 (1, “i”) УПК Российской Федерации (ст. 13 (1) УК).

Среди оснований для отказа от экстрадиции, предусматриваемых национальными законодательными актами, специального упоминания заслуживает невыдача лица за деяния политического характера ${ }^{55}$, хотя

об экстрадиции Португалия сделала оговорку о том, не будет выдавать лиц, экстрадиция которых затребована в связи с деянием, наказуемым пожизненным лишением свободы. Таким образом, не только смертүая казнь, но и пожизненное заключение по законодательству запрашивающего государства является основанием для отказа от выдачи лица.

${ }^{54}$ Plachta $M$. Non-Extradition of Nationals - A Never Ending Story // Emory Intemational Law Review. 1999. Vol. 13. № 1. P. 77-159; Zilbershats Y. Extradition Israeli Citizens to the United States - Extradition and Citizenship Dilemmas // Michigan Journal of International Law. 2000. Vol. 21. № 2. P. 297-326; Сафаров H. Отказ от экстрадиции собственных граждан: международное право и национальное законодательство // Азербайджанский юридический журнал. 2002. № 2. С. 129-148.

${ }^{55}$ Garcia - Mora M. The Nature of Political Offences: A Knotty Problem of Extradition Law // Virginia Law Review. 1962. Vol. 48. P. 1226-1230; Van den Wyngaert C. The Political Offence Exception to Extradition: the Delicate Problem of Balancing the Rights of the Individual and the International Public Order. Kluwer International. Dewenter. 1980; Felclin P. Das Politische Delict: Entwiclung, Problematic und Wandel im Auslieferungsrecht: unter Berucksichtigung der Rechtsprechung des Schweizerichts. Zurich 1979; Torsten S. Die Auslieferungsausnahme bei politischen Delicten: normative Grenzen, Anwendung in der Praxis und Versuch einer Neuormulierung. Berlin: Springer Verl. 1983; Phillips $S$. The Political Offence Exception and Terrorism: Its Place in the Current Extradition Scheme and Proposals for Its Future // Dickinson Journal of International Law 1997. Vol. 15. № 2. P. 347348; Van der Wilt $C$. The Political Offence Exception in Extradition Law: an Antidote to Prefixed Ideas About Political Integration in Europe? // Maastricht Journal of European and Comparative Law. 1997. Vol. 4. № 1. P. 25-58; Cervasio $C$. Extradition and the International Criminal Court: The Future of Political Offence Doctrine // Pace International Law Review. 
в последнее время подход, основанный на ограничении выдачи за политические преступления, подвергается серьезной критике, и прежде всего в связи с развернувшейся широкомасштабной борьбой с международным терроризмом. Более того, в некоторых сферах международного сотрудничества, связанных с доставкой обвиняемых запрашивающему государству, характер преступления не является юридическим препятствием для осуществления требуемых принудительных действий. В частности, это связано с введением с 1 января 2004 г. странами Евросоюза Европейского ордера на арест (ЕОА). Передача лица согласно ЕОА осуществляется без рассмотрения того, какого рода деяние (политическое либо общеуголовное) совершено лицом. Уровень развития защиты прав человека в масштабах объединения, по мнению стран Евросоюза, исключает саму постановку вопроса о возможности преследования по политическим мотивам ${ }^{56}$. Причем это подтверждается в отдельных случаях и на конституционном уровне. Например, согласно ст. 16а (1) Конституции Германии, лица, преследуемые по политическим мотивам, пользуются правом убежища. В то же время часть 2 ст. 16а предусматривает, что на это право не могут ссылаться лица, въезжающие из государства - участника Европейских Сообществ ${ }^{57}$. Тем не менее, в отличие от передачи лиц согласно ЕОА, при рассмотрении экстрадиции обвнняемого либо осужденного вопрос о характере преступления обязательно подвергается детальной оценке, и если деяние, которым обоснован запрос иностранного государства, является, по мнению, запрашиваемого государства, политическим, то имеет место отказ от экстрадиции.

1999. Vol. 11. № 2. P. 419-446; Branick $M$. Extradition and the Conflict of Nothem Ireland: The Past, Present and Future of an Intractable Problem // Hastings International and Comparative Law Review. 2002. Vo1. 25. № 2. P. 169-198; Gezón González C., López Ortega J.J. Derecho extradicional. Madrid: Dycinson, 2003 и др.

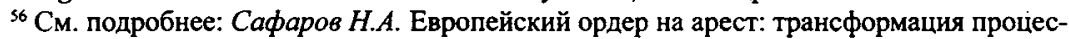
са экстрадиции // Московский журнал международного права. 2003. № 4. С. 196-214; Vennemann $N$. The European Arrest Warrant and Its Human Rights Implications // Zeitschrift für ausländisches öffentliches Recht und Völkerrecht. 2003. № 1. S. 103-121; Plachta M. European Arrest Warrant: Revolution in Extradition? // European Journal of Crime, Criminal Law and Criminal Justice. 2003. Vol. 11. № 2. P. 178-194; Alegre S., Leaf M. Mutual Recognition in European Judicial Cooperation: A Step Too Far Too Soon? Case Study -the European arrest warrant // European Law Journal. 2004. Vol. 10. № 2. P. 200-217; Wouters $J$. A., Naert F. Arrest Warrants, Terrorist Offences and Extradition Deals: An Appraisal of the EU'S Main Criminal Law Measures Against Terrorism After "11 September" //Common Market Law Review. 2004. Vol. 41. № 4. P. 909-935.

${ }^{57}$ Grundgesetz für die Bundesrepublik Deutschland. Bonn. 2003. S. 41. 
Согласно ст. 2A(b) израильского закона об экстрадиции, лицо не может быть выдано запрашивающему государству за преступление политического характера. Румынский закон о выдаче от 7 июня 2001 г. согласно ст. 9 не допускает экстрадиции, которая запрашивается за политическое преступление либо деяние, связанное с подобным преступлением.

Французский УПК (ст. 696-4 (2)) не допускает выдачу лица, если преступление, которым оно обосновывается, носит политический характер или проистекает из обстоятельств, когда экстрадиция запрашивается в политических целях.

Аналогичного подхода придерживается и законодательство Азербайджанской Республики. Согласно ст. 3.1.3 Закона о выдаче, в экстрадиции лица отказывается в случае, если деяние, совершенное запрашиваемым лицом и являющееся основанием для выдачи, признается Азербайджанской Республикой в качестве преступления политического характера. При этом целью исключения выдачи лиц, совершивших политическое преступление, является, с одной стороны, предупреждение экстрадиции, которая может иметь своим последствием предвзятость уголовного преследования и наказания лица, основанную на соображениях политического свойства, и, с другой стороны, недопущение вмешательства Азербайджанской Республики во внутриполитические конфликты в других государствах.

В указанной связи возникает закономерный вопрос - что же следует понимать в качестве политического преступления? Прежде всего необходимо отметить, что подавляющее большинство государств предусматривают наказуемость деяний, посягающих на государственные интересы: суверенитет, политическую независимость, обороноспособность и т.д. Подобные деяния включены в уголовные кодексы Российской Федерации (ст. 275, 276, 277, 278, 278), Франции (ст. 411-1, 411-2, $411-6,412-1$ ), Испании (ст. 581, 582, 584, 590, 595), Германии (ст. 81, $83,87,94,98)$ и т.д. В правовой доктрине они относятся к т.н. «политическим преступлениям». Наказуемость указанных преступлений подчиняется правилам, которые установлены в отношении всех иных уголовных деяний, другими словами, уголовное законодательство не предусматривает никакого специального режима для преследования преступлений, входящих в данную категорию.

Хотя национальные законы об экстрадиции используют термины «политическое преступление», «преступление политического харак- 
тера», вместе с тем ни договоры, ни внутреннее законодательство не предусматривают соответствующей дефиниции подобных деяний. Исключением из общего правила является лишь уголовное законодательство Италии, которое квалифицирует в качестве политического преступления деяние, посягающее на политические интересы государства или политические права гражданина. Политическим считается также общеуголовное деяние, совершенное в целом или в части по политическим мотивам ${ }^{58}$. Во всех случаях определение политического характера преступления - вопрос внутренней компетенции запрашиваемого государства, его правовой практики, как правило, решаемый в судебном порядке. Следует вместе с тем принять во внимание, что национальные законы не допускают расширительного толкования категории «политического преступления», последовательно исключая некоторых лиц, совершивших подобные деяния, из сферы правовой защиты. «Деполитизация» таких преступлений, как геноцид, преступления против человечности, военные преступления, терроризм и т.д., преследует цель сделать возможной экстрадицию лиц, виновных в их совершении, и обеспечить неотвратимость ответственности и наказания. Примеры подобной «деполитизации» можно найти в законах Великобритании, Азербайджана и других стран. Например, согласно ст. 23 (1) Закона Великобритании об экстрадиции для его целей настоящего закона никакое преступление, которое наказывается как геноцид либо как покушение, сговор или подстрекательство к совершению такого преступления, не рассматривается как преступление политического характера.

Более развернутая «деполитизация» содержится в Законе Азербайджанской Республики о выдаче, примечание к ст. 3 которого предусматривает, что геноцид, преступления против человечности и военные преступления как они определены в Женевских конвенциях 1949 г., тяжкие и особо тяжкие преступления против жизни, здоровья, безопасности и свободы человека, а также деяния, уголовная ответственность за совершение которых предусмотрена международными договорами Азербайджана, не признаются для целей выдачи в качестве политического преступления.

В числе «деполитизируемых» преступлений следует, конечно же, упомянуть терроризм ${ }^{59}$. Как известно, большинство международных

58 Уголовное право зарубежных государств. Общая часть / Под ред. И.Д. Козочкина. M., 2001. C. 519. 
юридических инструментов в сфере борьбы с терроризмом уделяют данному вопросу пристальное внимание. Например, Конвенция о борьбе с бомбовым терроризмом от 16 декабря 1997 г. в ст. 11 устанавливает, что ни одно из преступлений, указанных в ст. 2 Конвенции, не рассматривается для целей выдачи как политическое преступление либо преступление, связанное с политическим преступлением, или преступление, вызванное политическими мотивами. Однако, несомненно, важнейшим международно-правовым документом, «деполитизирующим» терроризм, является Европейская конвенция о борьбе с терроризмом 1977 г., которая, не допуская отнесения целого ряда терактов к категории политических преступлений, сделала возможной экстрадицию террористов. Причем сфера «деполитизации» была существенно расширена после принятия 15 мая 2003 г. Протокола к указанной конвенции ${ }^{60}$. Если в ранее действовавшей редакции ст. 1 Конвенции предусматривались лишь шесть категорий деяний, включая и покушение на преступление, которые не расценивались в качестве политических, то измененная редакция предусматривает десять подобных деяний. Причем вместо общих формулировок подпараграфов с, d, е ст. 1 перечисляет конкретные международные соглашения по борьбе с отдельными преступлениями, которые не рассматриваются в качестве политических деяний для целей выдачи ${ }^{61}$. В качестве отдельного пункта выделе-

${ }^{39}$ CM.: Phillips $S$. The Political Offence Exception and its Place in the Current Extradition Scheme and Proposals for its Future // Dickinson Journal of International Law. 1997. Vol. 15. № 2. P. 337-359. См. подробнеe: Lubet S. Extradition Reform: Executive Discretion and Judicial Participation in the Extradition of Political Terrorists // Comell International Law Journal. 1982. Vol. 15. № 2; Terrorism and International Law / Ed. by Higgins and M. Flory. London / New-York: Routlege, 1997; Cases and Materials on Terrorism / ed. by Noone M. and Alexander Y. Kluwer Law International: The Hague. 1997.

${ }^{60}$ CM.: Protocol Amending the European Convention on the Suppression of Terrorism // [WWW - сайт]: URL: wWw.conventions.coe.int

${ }^{61}$ Согласно ст. 1 Конвенции (видоизмененной), для целей экстрадиции между договаривающимися государствами не рассматриваются в качестве политических преступления в рамках следующих международных соглашений: Конвенции о предотвращении и наказании преступлений против лиц, полььзующихся международной защитой от 17 декабря 1973 г., Международной конвенции о борьбе с захватом заложников от 17 декабря 1979 г., Конвенции о физической защите ядерного материала от 3 марта 1980 г., Протокола о борьбе с незаконными актами насилия в аэропортах, обслуживающих гражданскую авиацию, дополняющего Конвенцию о борьбе с незаконными актами, направленными против безопасности гражданской авиации от 24 февраля 1988 г., Конвенции о борьбе с незаконными актами, направленными против безопасности морского судоходства от 10 марта 1988 г., Международной конвенции о борьбе с бомбовым терроризмом от 15 декабря 1997 г., Протокола о борьбе с незаконными актами, 
но покушение на совершение указанных в ст. 1 преступлений, которое также не рассматривается в качестве политичиеского преступления. Новая редакция ст. 1 дополнена параграфом 2, который предусматривает, что для целей экстрадиции между Договаривающимися Государствами не будут рассматриваться в качестве политических преступлений также попытка совершения одного из вышеуказанных деяний, участие в качестве сообщника лица, которое совершает или пытается совершить любое из указанных преступлений, организация совершения или направление других лиц на совершение или попытки совершить любое из указанных преступлений ${ }^{62}$.

Имплементация подходов указанных конвенций в национальном законодательстве в связи с растущей угрозой терроризма представляется чрезвычайно важной. Нельзя допускать того, чтобы террористы использовали различного рода «лазейки» в международном праве и национальном законодательстве для прикрытия своей преступной деятельности, оставаясь безнаказанными ${ }^{63}$.

Предмет регулирования национальных законов охватывает также выдачу правонарушителей в коллизионных ситуациях, когда с запросом об экстрадиции обрашаются несколько государств. Подобные ситуации нередки в международной практике и возникают они вследствие того, что лицом совершаются преступления на территориях нескольких государств, каждое из которых проявляет заинтересованность в наказании преступника. С другой стороны, на уголовную юрисдикцию могут притязать страны, против интересов либо граждан которых направлено преступление, хотя оно и было совершено не на их собственной территории. Сказанное не исключает и других вариантов конкурирующей юрисдикции.

В подобных ситуациях Закон Азербайджанской Республики о выдаче предусматривает следующее:

направленными против безопасности стационарных платформ, раслоложенных на континентальном шельфе от 10 марта 1988 г., Международной конвенции о борьбе с финансированием терроризма от 9 декабря 1999 г.

${ }^{62} \mathrm{C}_{\mathrm{M}}$.: The Fight Against Terrorism - Council of Europe Standarts. Council of Europe Publishing. 2004.

${ }^{63}$ Terrorism and International Legal Order / Ed. by Peter J. van Krieken. Cambridge: Cambridge University Press. 2002; Knoops A. Intemational terrorism: the Changing Face of International extradition and European Criminal Law // Maastricht Journal of European and Comparative Law. 2003. Vol. 10. № 2. P. 149-167; Enforcing International Law Norms Against Terrorism / Ed. by Andrea Bianchi. Oxford: Hart Publishing. 2004. 
во-первых, согласно ст. 12.1 запрашиваемое лицо, как правило, выдается государству, на территории которого было совершено преступление;

во-вторых, в соответствии со ст. 12.2, если преступление или преступления, являющиеся основанием для выдачи, совершены на территориях нескольких государств и каждое из них запрашивает выдачу лица, при решении вопроса об экстрадиции принимаются во внимание тяжесть совершенного преступления, другие фактические обстоятельства дела, гражданство лица, совершившего преступление, и дата представления запроса. Позиция национального закона близка к правовым подходам Европейской конвенции об экстрадиции 1957 r., в ст. 17 предусматривающей схожее решение вопроса об экстрадиции при наличии конкурирующих запросов.

Французский УПК (ст. 696-5) предусматривает несколько вариантов преодоления коллизионных ситуаций. В соответствии с указанной статьей, если по одному и тому же преступлению экстрадицию требуют несколько государств, то предпочтение оказывается тому государству, против интересов которого было направлено это правонарушение, или же тому государству, на чьей территории оно было совершено. Если же конкурирующие требования об экстрадиции имеют основанием различные преступления, то для того, чтобы определить право первоочередности, учитываются все обстоятельства дела, и в частности: относительная тяжесть совершения правонарушения и место его совершения, дата подачи запроса, обязательство, которое было бы взято на себя одним из запрашивающих государств на реэкстрадицию.

Однако применение такого критерия, как тяжесть преступления, ввиду его оценочного характера нельзя признать бесспорным.

Институт международного права в Оксфордской резолюции (ст. 9) предлагал при наличии нескольких требований о выдаче за одно и то же деяние отдавать предпочтение государству, на территории которого было совершено данное преступление ${ }^{64}$. Подобный подход нашел отражение и в известном Гарвардском проекте Конвенции об экстрадиции, предусматривавшей в случае конкуренции запросов о выдаче отдавать предпочтение требованию государства, обладающего территориальной юрисдикцией ${ }^{65}$.

\footnotetext{
${ }^{64}$ American Journal of International Law. 1935. № 1. P. 300-301.

${ }^{65}$ Supplement to the American Journal of International Law. 1935. № 1-2. P. 14-22.
} 
Таков в общих чертах основной круг вопросов, который входит в предмет регулирования национальных законов, обеспечивающих прочный правовой фундамент для решения конкретных вопросов экстрадиции при отсутствии международного договора. 